Anna Michalak

\title{
Zasada suwerenności a ochrona porządku konstytucyjnego. Kilka uwag \\ o roli organizacji międzynarodowych w utrzymaniu bezpieczeństwa ustrojowego państw członkowskich
}

http://dx.doi.org/10.18778/8088-830-2.07

W dobie globalizacji i powszechnej przynależności państw do instytucji ponadnarodowych warto zastanowić się nad potencjalnymi zmianami, jakie te zjawiska wywołują w sferze wykładni konstytucji krajowych, ich charakteru i pełnionej funkcji. Choć konkretna ustawa zasadnicza jest ściśle związana z określonym państwem, stanowiąc jednocześnie symbol jego suwerenności, jak i instrument legitymujący sprawowanie rządów, to jednocześnie odgrywa ona rolę w międzynarodowym porządku prawnym, osadzając funkcjonowanie instytucji międzynarodowych i unormowania międzynarodowe $\mathrm{w}$ krajowym systemie prawa.

W wyroku z dnia 24 listopada 2010 r. (sygn. akt K 32/09)1 dotyczącym Traktatu z Lizbony ${ }^{2}$ Trybunał Konstytucyjny wskazał, że zasada zachowania suwerenności w procesie integracji europejskiej wymaga respektowania konstytucyjnych granic przekazywania kompetencji. Do istoty suwerenności, a tym samym do kompetencji nieprzekazywalnych, zaliczył zwłaszcza stanowienie reguł konstytucyjnych i kontrolę ich przestrzegania, wymiar sprawiedliwości, władzę nad własnym terytorium państwa, armią i siłami zapewniającymi bezpieczeństwo oraz porządek publiczny. W tym względzie decydujące uprawnienia mają właściwe władze Rzeczypospolitej. Konkretyzacją zasady zachowania suwerenności w procesie integracji europejskiej jest właśnie wykluczenie nadaniu przekazania

${ }^{1}$ OTK ZU nr 9/A/2010, poz. 110

2 Traktat z Lizbony zmieniający Traktat o Unii Europejskiej i Traktat ustanawiający Wspólnotę Europejska, sporządzony w Lizbonie dnia 13 grudnia 2007 r. (Dz.U. z 2009 r., nr 203, poz. 1569). 
kompetencji „charakteru uniwersalnego”, a zarazem zakaz przekazania „W całości kompetencji najważniejszych”, a ponadto uzależnienie przekazania kompetencji od dochowania specjalnej procedury określonej w art. 90 Konstytucji. Wymieniona zasada wyklucza uznanie, że podmiot, któremu kompetencje przekazano, może samodzielnie rozszerzać ich zakres.

W doktrynie prawa reprezentowane są dwa różne stanowiska co do znaczenia aktu przekazywania kompetencji na rzecz UE dla suwerenności państw członkowskich. Zdaniem niektórych autorów, przekazywanie kompetencji państwowych stanowi formę ograniczenia suwerenności państw członkowskich. Zdaniem innych badaczy, przekazywanie kompetencji stanowi jedynie formę ograniczenia wykonywania suwerenności. Odmienność poglądów wynika z tego, że jedni suwerenność definiują jako wiązkę kompetencji, z których część może być przekazana organowi lub organizacji międzynarodowej, co skutkować będzie zawężeniem posiadanego przez państwo zakresu kompetencji, a tym samym owym ograniczeniem suwerenności. Inni z kolei suwerenność definiują jako cechę (przymiot) państwa, która przysługuje w całości lub w ogóle, a zatem nie może zostać ograniczona $\mathrm{w}$ razie przekazania organowi lub organizacji międzynarodowej określonych uprawnień w sferze stanowienia czy stosowania prawa. Suwerenność oznacza bowiem zdolność do decydowa86 nia przez państwo o sposobie wykonywania swoich kompetencji. To, czy kompetencje te państwo będzie wykonywać samodzielnie, czy też deleguje je na inne podmioty z punktu widzenia owej zdolności do decydowania („kompetencji kompetencji”), nie ma żadnego znaczenia. Jedynie wówczas, gdyby przekazanie kompetencji wiązało się z utratą zdolności do decydowania o sposobie ich wykonywania, a zatem $\mathrm{z}$ utratą owej "kompetencji kompetencji”, i miałoby przy tym nieodwracalny charakter, moglibyśmy mówić o utracie cechy definiującej państwo, czyli właśnie suwerenności ${ }^{3}$. Taki pogląd prezentuje również TK, który w powołanym wyżej wyroku, odnosząc się do problemu kompetencji przekazanych przez państwo członkowskie na rzecz UE, stwierdził: „w sferze kompetencji przekazanych państwa zrzekły się uprawnienia do podejmowania autonomicznych działań prawodawczych w stosunkach wewnętrznych i międzynarodowych, co jednak nie prowadzi do trwałego ograniczenia suwerennych praw tych państw, ponieważ przekazanie kompetencji nie jest nieodwracalne, a relacje między kompetencjami wyłącznymi i konkurencyjnymi mają charakter dynamiczny. Państwa Członkowskie przyjęły jedynie zobowiązanie do wspólnego wykonywania funkcji państwowych

${ }^{3}$ Pisze o tym szerzej J. Ciapała, Wokót pojmowania $i$ wykonywania suwerenności w warunkach członkostwa w Unii Europejskiej - kilka uwag podstawowych, lecz czy wystarczajacych?, „Gdańskie Studia Prawnicze” 2014, t. XXXI, s. 83 i n. 
w dziedzinach objętych współpracą i dopóki utrzymają pełną zdolność do określania form wykonywania funkcji państwowych, [...] pozostaną w świetle prawa międzynarodowego podmiotami suwerennymi".

Także w myśl art. 4 ust. 2 Traktatu o Unii Europejskiej (dalej: TUE) ${ }^{4}$ bezpieczeństwo narodowe pozostaje w zakresie wyłącznej odpowiedzialności każdego Państwa Członkowskiego. Przepis ten stanowi, że Unia szanuje równość Państw Członkowskich wobec Traktatów, jak również ich tożsamość narodowa, nierozerwalnie związaną z ich podstawowymi strukturami politycznymi i konstytucyjnymi, w tym w odniesieniu do samorządu regionalnego i lokalnego. Szanuje podstawowe funkcje państwa, zwłaszcza funkcje mające na celu zapewnienie jego integralności terytorialnej, utrzymanie porządku publicznego oraz ochronę bezpieczeństwa narodowego. W szczególności bezpieczeństwo narodowe pozostaje w zakresie wyłącznej odpowiedzialności każdego Państwa Członkowskiego.

Bezpieczeństwo jako jedno z dóbr podlegające ochronie prawnej nie zostało jednak zdefiniowane w żadnym krajowym akcie prawnym. Jedynie $\mathrm{w}$ doktrynie oraz literaturze przedmiotu pojęcie to bywa różnie określane i przypisuje się mu różną pojemność semantyczną.

Podsumowując przegląd regulacji konstytucyjnej, należy zauważyć, że termin „bezpieczeństwo" pojawia się kilkakrotnie w przepisach ustawy zasadniczej. Nie występuje on samodzielnie. Powiązany jest z dookreśleniem rodzaju bezpieczeństwa. Mamy więc do czynienia z bezpieczeństwem postrzeganym podmiotowo: obywateli; państwa; konsumentów, użytkowników i najemców oraz przedmiotowo: wewnętrznym; zewnętrznym; ekologicznym oraz z bezpiecznymi warunkami pracy ${ }^{5}$.

Podstawowym unormowaniem jest art. 5 ustawy zasadniczej przesądzający, że Rzeczpospolita Polska strzeże niepodległości i nienaruszalności swojego terytorium oraz zapewnia m.in. prawa i wolności człowieka i obywatela, a także bezpieczeństwo obywateli. W doktrynie podkreśla się, że pod względem charakteru normatywnego art. 5 ustawy zasadniczej jest normą programową wyznaczającą kierunek działalności państwa, zobowiązując go do podjęcia działań zmierzających do urzeczywistnienia wskazanych w treści przepisu wartości konstytucyjnych. Normy programowe nakazują dążenie do osiągnięcia przez wskazanego przez ustrojodawcę celu. Dążenie to powinno znaleźć odzwierciedlenie w działaniach podejmowanych przez organy administracji publicznej realizujących funkcje państwa. Dzięki normom programowym porządek ustrojowy jest dynamiczny i łatwiej dostosować się do zmiennych warunków społecz-

\footnotetext{
${ }^{4}$ Dz.Urz. C 202 z 07.06.2016, s. 1-388.

${ }^{5}$ Szerzej na ten temat zob. A. Bień-Kacała, Bezpieczeństwo w Konstytucji RP z 1997 r. - wstępna diagnoza, „Przegląd Prawa Konstytucyjnego” 2015, nr 2, s. 11 i n.
} 
no-gospodarczych lub politycznych. Nie wskazują jednak, jak należy się zachować, jakie podejmować przedsięwzięcia, w jakich formach działać i jakimi środkami się posłużyć, aby zrealizować cel wyznaczony przez ustawodawcę konstytucyjnego. W przypadku normy programowej to adresat powinien dokonać analizy prakseologicznej, na podstawie której powinien podjąć takie działania, które doprowadzą do realizacji założonego celu. Z tego punktu widzenia istotny jest cel, a nie środki, które doprowadzą do jego realizacji ${ }^{6}$.

Nie ulega przy tym wątpliwości, że adresatem unormowania art. 5 Konstytucji jest państwo, a wynikający z niego obowiązek ma charakter bezwzględny i państwo nie może się od niego uchylić. Obowiązek ten aktualizuje się przede wszystkim w sytuacji zagrożenia, kiedy w systemie prawnym nie ma szczegółowej normy kompetencyjnej uprawniającej lub zobowiązującej organy władzy publicznej do działania ${ }^{7}$.

W doktrynie prawa konstytucyjnego przyjmuje się zatem, że w świetle art. 5 Konstytucji to trzy elementy łącznie, tj. ludność, terytorium oraz system władzy, powinny być przedmiotem szczególnej ochrony państwa. W szeroko rozumianym pojęciu systemu bezpieczeństwa państwa można więc wyróżnić $m$.in. następujące ściśle ze sobą powiązane podsystemy:

- bezpieczeństwa politycznego (ma na celu ochronę interesów państwa metodami politycznymi),

- bezpieczeństwa militarnego (ma na celu zapewnienie obrony w wypadku konfliktu zbrojnego),

- bezpieczeństwa gospodarczego (ma na celu chronić rozwój gospodarczy Polski),

- bezpieczeństwa publicznego (ma na celu zapewnić porządek konstytucyjny, ochronę przed sytuacjami kryzysowymi, zagrożeniami środowiska, zapewnić porządek publiczny oraz ochronę przed zjawiskami kryminogennymi),

- bezpieczeństwa socjalnego (ma na celu zapewnić podstawowe warunki do godnej egzystencji człowieka-obywatela) ${ }^{8}$.

W konstytucji wyróżniono także bezpieczeństwo zewnętrzne i wewnętrzne. Wskazać należy, że rozdzielenie definicyjne tych rodzajów bezpieczeństwa może być utrudnione $z$ uwagi na tożsame rodzaje zagrożeń tych kategorii. Bezpieczeństwo zewnętrzne łączy się z suwerennościa, niepodległością i integralnością terytorialną (nienaruszalnością granic)

${ }^{6}$ W. Lis, Bezpieczeństwo wewnętrzne i porzadek prawny jako sfera działania administracji publicznej, Lublin 2015, s. 129 i wskazana tam literatura.

7 Por. K. Wojtyczek, Konieczność jako legitymizacja działań władzy w demokratycznym państwie prawnym, „Państwo i Prawo” 1994, nr 9, s. 40-41.

${ }^{8}$ H. Zięba-Załucka, Konstytucyjne aspekty bezpieczeństwa, "Studia Iuridica Liblinensia" 2014, nr 22, s. 418. 
państwa. Dotyczy ono głównie zagrożeń militarnych w otoczeniu organizacji państwowej. Bezpieczeństwo wewnętrzne natomiast odnoszone jest do kategorii porządku prawnego, życia i zdrowia obywateli, majątku narodowego w kontekście klęsk żywiołowych, katastrof naturalnych oraz awarii technicznych. Ta sfera dotyczy przede wszystkim możliwości sprawnego funkcjonowania organów publicznych (bezpieczeństwa ustrojowego, choć sam ustrojodawca rozróżnił bezpieczeństwo wewnętrzne od porządku publicznego) $)^{9}$. Bezpieczeństwo państwa łączy w sobie aspekt zewnętrzny i wewnętrzny, tworząc odrębną wartość konstytucyjną ${ }^{10}$.

Zgodzić należy się z konstatacją że słowo „bezpieczeństwo” odnosi się do szerokiego spektrum dziedzin życia i działalności państwa. W piśmiennictwie oraz polemice publicznej pojęcie bezpieczeństwa wewnętrznego jest porównywane $z$ bezpieczeństwem publicznym. Te dwa rodzaje bezpieczeństwa mogą być uważane za synonimy, jednak przy dokładniejszej analizie są określane inaczej. Trzeba jednak przyznać, że zdefiniowanie pojęć związanych $z$ bezpieczeństwem wewnętrznym jest kłopotliwym zadaniem, także stan badań naukowych $\mathrm{w}$ tym obszarze jest mizerny ${ }^{11}$.

W doktrynie nie ma jednak wątpliwości co do tego, że elementem bezpieczeństwa publicznego jest bezpieczeństwo ustrojowe, które ochrania i poręcza porządek konstytucyjny. Pojęcie to jest najściślej związane $\mathrm{z}$ państwem $\mathrm{w}$ jego tradycyjnym, instytucjonalnym rozumieniu. Bezpieczeństwo ustrojowe opiera się na konstytucji. Akt ten zakreśla treść bezpieczeństwa ustrojowego, wskazując na jego trzy składniki, będące zarazem stałym elementem współczesnych konstytucji. Po pierwsze, zasady ogólne, które wskazują na przyjęty w państwie katalog wartości określający charakter państwa. Po drugie, system naczelnych organów państwa, ich kompetencje i wzajemne relacje, określane mianem reżimu politycz-

${ }_{9}$ Zob. art. 31 ust. 3, art. 53 ust. 5, art. 61 ust. 3, art. 230 ust. 1 Konstytucji oraz B. Banaszak, Konstytucja Rzeczypospolitej Polskiej. Komentarz, Warszawa 2012, s. 220 i 791. Niektóre poglądy nieco rozszerzają materię bezpieczeństwa wewnętrznego, ujmując w jego ramach nie tylko problematykę natury represyjnej, a więc porządku konstytucyjnego i bezpieczeństwa publicznego, lecz także bezpieczeństwa powszechnego. $W$ tym ujęciu bezpieczeństwo publiczne oznacza stan przejawiający się ochroną porządku prawnego, życia i zdrowia obywateli oraz majątku narodowego przed bezprawnymi działaniami. Z kolei bezpieczeństwo powszechne to stan zapewniający ochronę życia i zdrowia obywateli oraz majątku narodowego przed skutkami klęsk żywiołowych i katastrof technicznych (B. Wiśniewski, S. Zalewski, D. Podleś, K. Kozłowska, Bezpieczeństwo wewnętrzne Rzeczypospolitej Polskiej, Warszawa 2004, s. 12).

10 A. Bień-Kacała, Bezpieczeństwo..., s. 18.

${ }^{11}$ Szerzej na ten temat zob. H. Zięba-Załucka, Konstytucyjne aspekty..., s. 426 oraz W. Lis, Bezpieczeństwo wewnętrzne..., s. 21 i n.; A. Osierda, Prawne aspekty pojęcia bezpieczeństwa publicznego i porządku publicznego, „Studia Iuridica Lublinensia” 2014, nr 23, s. 89 i n., http://studiaiuridica.umcs.pl (dostęp 02.03.2017). 
nego (systemu rządów). Po trzecie, katalog wolności i praw człowieka i obywatela, który wyznacza władzom reguły, obszar oraz intensywność możliwych ingerencji, pełniąc funkcje gwaranta stosunków państwo-obywatel-człowiek ${ }^{12}$.

Należy przyjąć, że kolejnym elementem bezpieczeństwa ustrojowego jest także wynikająca z preambuły do konstytucji - adresowana do ustawodawcy - zasada rzetelności i sprawności działania instytucji publicznych $^{13}$. Zasada ta wyznacza konstytucyjne kryteria oceny przepisów regulujących ustrój i procedurę działania instytucji publicznych.

Pierwszym kryterium jest sprawność, którą należy rozumieć jako zdolność instytucji publicznej do realizacji przyznanych jej prawem kompetencji. Przejawia się ona w jednoznacznej i spójnej regulacji ustawowych kompetencji oraz procedury działania danej instytucji. Konstytucyjnego kryterium sprawności nie spełnia ustawa zarówno wyłączająca wprost konstytucyjną kompetencję organu władzy publicznej, jak i regulująca ją w sposób niespójny, nakazując organowi: a) dokonanie czynności, które są ze sobą sprzeczne; b) dokonanie w tym samym czasie dwóch lub więcej czynności, których nie można dokonać równocześnie; c) dokonanie dwóch czynności, z których jedna czynność niweczy skutek drugiej czynności. Ocena spełniania przez ustawodawcę wymogu sprawności 90 działania instytucji publicznej wymaga zatem uwzględnienia albo konstytucyjnej normy kompetencyjnej organu albo konstytucyjnych gwarancji procedury właściwej dla tego organu.

Drugim kryterium jest rzetelność, którą należy rozumieć jako zdolność działania instytucji publicznej w sposób wiarygodny dla podmiotów prawa. Rzetelność związana jest z przewidywalnością przesłanek oraz konsekwencji działania instytucji publicznych, a ponadto wymaga, by działaniom tym nadano właściwą formę oraz je udokumentowano. Konstytucja zapobiega w ten sposób zakwestionowaniu zgodnego z prawdą i wiarygodnego publicznie działania jednych organów państwa demokratycznego przez jego inne organy (np. ustawodawcę). Przepisy ustawowe, które podważają rzetelność działania instytucji publicznych, mogą prowadzić wszakże do delegitymizacji tych instytucji. W tym sensie kryterium rze-

${ }_{12}$ Por. A. Sekściński, Bezpieczeństwo wewnętrzne w ujęciu teoretycznym. Geneza $i$ wspótczesne rozumienie w naukach politycznych, „Kwartalnik Naukowy OAP UW e-Politikon" 2013, s. 70 i n., http://oapuw.pl/e-politikon-nr-62013/ (dostęp 29.12.2016).

${ }^{13}$ Zasada ta wielokrotnie była przedmiotem rozważań w orzecznictwie konstytucyjnym (m.in. wyroki TK z: 12 marca 2007 r., sygn. akt K 54/05, OTK ZU nr 3/A/2007, poz. 25; 7 stycznia 2004 r., sygn. akt K 14/03, OTK ZU nr 1/A/2004, poz. 1; 7 listopada 2005 r., sygn. akt P 20/04, OTK ZU nr 10/A/2005, poz. 111; 22 września 2006 r., sygn. akt U 4/06, OTK ZU nr 8/A/2006, poz. 109; 15 stycznia 2009 r., sygn. akt K 45/07, OTK ZU nr 1/A/2009, poz. 3; wyrok z 14 października 2015 r., sygn. akt Kp 1/15, OTK ZU nr 9/A/2015, poz. 147). 
telności chronić ma państwo in toto przed autodelegitymizacją. Trybunał przypomina, że państwo, by mogło być szanowane przez obywateli, musi szanować własne decyzje oraz rzetelność działań własnych organów. Państwo, które nie szanuje własnych decyzji, nie może oczekiwać szacunku i zaufania od swoich obywateli. Konstytucyjnego kryterium rzetelności nie spełnia w szczególności powierzenie przez ustawodawcę danej instytucji publicznej takiej kompetencji lub ustanowienie takiej procedury, które podważałyby zaufanie do państwa, jego organów oraz stanowionego i stosowanego przez nie prawa.

Trzecim kryterium jest efektywność, którą należy rozumieć jako zdolność działania instytucji publicznej: a) niezwłocznie, gdy przepisy konstytucyjne tak stanowią (np. art. 190 ust. 2 Konstytucji), b) w terminach konstytucyjnie wyznaczonych (np. art. 122 ust. 2 Konstytucji) albo c) bez nieuzasadnionej zwłoki, gdy przepisy konstytucyjne nie przewidują ani obowiązku niezwłocznego działania, ani nie stanowią o terminach wprost (np. art. 45 ust. 1 Konstytucji). Efektywność zależy zatem od czynnika czasu w działalności instytucji publicznych i jego znaczenia dla kształtowania się stosunków prawnych. Konstytucyjnemu kryterium efektywności nie odpowiada w szczególności regulacja skutkująca bezterminowym zawieszeniem postępowania albo wydłużeniem postępowania w sposób nieuzasadniony wartościami konstytucyjnymi ${ }^{14}$.

Bezpieczeństwo ustrojowe, w przeciwieństwie do pozostałych pojęć współtworzących bezpieczeństwo wewnętrzne, dotyczy zatem kwestii związanych ze sprawowaniem władzy $^{15}$. Zgodnie z ogólnie przyjętymi definicjami, bezpieczeństwo ustrojowe dotyczy ładu instytucjonalnego i normatywnego państwa, tworzenia prawnych gwarancji swobód i wolności obywatelskich oraz tożsamości państwa. Z kolei porządek konstytucyjny określa charakter państwa - relacje pomiędzy instytucjami władzy, obowiązki oraz prawa i wolności obywatelskie ${ }^{16}$.

Należy podkreślić, że porządek konstytucyjny jest też kategorią społeczną. Zaufanie obywateli do instytucji publicznych bezpośrednio koresponduje ze zdolnościami państwa do zapewnienia bezpieczeństwa jego obywatelom. Władze państwa posiadają legitymację społeczną w zakresie tworzenia systemów bezpieczeństwa, które mają służyć przede wszystkim ludziom. W tym kontekście pojawiają się coraz częściej pytania o zakres władzy, jaki współczesna demokracja powinna posiadać w stosunku

${ }_{14}$ Zob. wyrok TK z dnia 11 sierpnia 2016 r., sygn. akt K 39/16, OTK ZU nr A/2016, poz. 71 .

${ }^{15}$ M. Brzeziński, Rodzaje bezpieczeństwa państwa, [w:] S. Sulowski, M. Brzeziński (red.), Bezpieczeństwo wewnętrzne państwa. Wybrane zagadnienia, Warszawa 2009, s. 41.

${ }^{16}$ B. Wiśniewski, S. Zalewski, D. Podleś, K. Kozłowska, Bezpieczeństwo wewnętrzne..., s. 24-30. 
do własnych obywateli. Problemy te mają charakter zarówno społeczny, jak i polityczny. Dlatego źródeł zagrożeń dla porządku konstytucyjnego współczesnego państwa można upatrywać także w samych instytucjach demokracji, w tym również tych, które zostały powołane do jej ochrony ${ }^{17}$.

W literaturze przedmiotu za niezbędne dla zachowania bezpieczeństwa ustrojowego uznaje się: dochowanie przez klasę polityczną wierności postanowieniom konstytucji i ustaw determinujących istotę ustroju politycznego Rzeczypospolitej Polskiej, dbanie o pozycję i autorytet Trybunału Konstytucyjnego, respektowanie zobowiązań międzynarodowych, kierowanie się $\mathrm{w}$ działalności politycznej nadrzędną wobec wszystkich innych zasad i celów racją stanu (interesem państwa), poszanowanie swobód obywatelskich, odchodzenie od praktyki finansowania partii politycznych z budżetu państwa, konsekwentne podejmowanie działań na rzecz budowy społeczeństwa obywatelskiego, zapewnienie sprawnego funkcjonowania sądów i prokuratur ${ }^{18}$. Gdy powyższe warunki nie są spełnione, aktualne staje się pytanie o to, kto w takiej sytuacji będzie uprawniony, ale i zobowiązany do ochrony porządku konstytucyjnego Rzeczypospolitej Polskiej.

Współczesne państwa coraz częściej decydują się na funkcjonowanie w ramach systemów międzynarodowych, co nierzadko oznacza „dzie92 lenie się" suwerennością. Przekazanie organizacji międzynarodowej lub organowi międzynarodowemu kompetencji organów władzy państwowej $\mathrm{w}$ niektórych sprawach $\mathrm{w}$ odpowiednim trybie (tj. $\mathrm{w}$ drodze ratyfikowanej umowy międzynarodowej, o której mowa w art. 90 Konstytucji) nie stanowi zagrożenia dla bezpieczeństwa ustrojowego. Co więcej, ustrojodawca przyjął, że taka umowa międzynarodowa ma pierwszeństwo przed ustawa, jeżeli ustawy tej nie da się pogodzić z umową (art. 91 ust. 2 Konstytucji), a jeżeli wynika to z ratyfikowanej przez Rzeczypospolitą Polską umowy konstytuującej organizację międzynarodową prawo przez nią stanowione jest stosowane bezpośrednio, mając pierwszeństwo w przypadku kolizji z ustawami (art. 91 ust. 3 Konstytucji).

Polska jest członkiem Rady Europy ${ }^{19}$, organizacji międzyrządowej, która powstała 5 maja 1949 r. Członkiem Rady Europy może zostać każde państwo europejskie akceptujące zasady rządów prawa, demokracji par-

17 A. Sekściński, Bezpieczeństwo wewnętrzne..., s. 75.

${ }_{18}$ W. Fehler, Bezpieczeństwo wewnętrzne wspótczesnej Polski. Aspekty teoretyczne i praktyczne, Warszawa 2012, s. 76.

${ }_{19}$ Statut Rady Europy przyjęty w Londynie dnia 5 maja 1949 r. (Dz.U.1994.118.565) oraz Oświadczenie rządowe z dnia 20 maja 1994 r.zw sprawie przystąpienia Rzeczypospolitej Polskiej do Statutu Rady Europy, przyjętego w dniu 5 maja 1949 r. w Londynie (Dz.U.1994.118.566), który wszedł w życie w stosunku do Polski dnia 26 listopada $1991 \mathrm{r}$. (dalej: Statut Rady Europy). 
lamentarnej i ochrony praw człowieka, zaproszone przez tę organizację do przystąpienia. Gwarancją przestrzegania tych wartości jest zobowiązanie się do ratyfikacji Europejskiej Konwencji Praw Człowieka (dalej: Konwencja $)^{20} \mathrm{w}$ przeciągu roku od przystąpienia do organizacji. Mandat RE określa Statut Rady Europy, a także dokumenty szczytów szefów państw i rządów RE, w tym w szczególności Trzeciego Szczytu RE w Warszawie. Co dwa lata KM przyjmuje program działań organizacji na kolejne dwa lata. Zgodnie z art. 1a Statutu celem Rady Europy jest osiąganie większej jedności między jej członkami dla ochrony ideałów i zasad, stanowiących wspólne dziedzictwo państw członkowskich oraz ułatwienie ich przemian ekonomicznych i społecznych. Z zakresu działania RE wyraźnie wyłączone przez Statut są sprawy obrony narodowej. W świetle dokumentów Trzeciego Szczytu RE podstawowa działalność Rady Europy dotyczy promowania i umacniania trzech wartości: praw człowieka, demokracji i praworządności w Europie. Rada Europy prowadzi szeroką działalność w zakresie tworzenia nowych standardów prawnych, rozwijania współpracy prawnej między państwami członkowskimi, rozwijania demokracji lokalnej. Działa także w obszarze kultury, edukacji, młodzieży, sportu, dziedzictwa kulturowego i naturalnego, dialogu międzykulturowego, zagospodarowania przestrzennego, a także w sprawach społecznych, zdrowia i migracji ${ }^{21}$.

Komisja Wenecka (Europejska Komisja na rzecz Demokracji przez Prawo) jest organem doradczym Rady Europy, złożonym z niezależnych ekspertów w dziedzinie prawa konstytucyjnego i międzynarodowego, sędziów i członków parlamentów narodowych. Mandat Komisji Weneckiej został określony w rezolucjach Rady Europy z 10 maja 1990 i z 21 lutego 2002 r. ustanawiających i modyfikujących Statut Komisji Weneckiej ${ }^{22}$.

Jej celem jest zapewnianie demokratycznego i sprawnego funkcjonowania instytucji demokratycznych oraz ochrona praw człowieka. Działalność Komisji Weneckiej koncentruje się przede wszystkim na udzielaniu pomocy technicznej indywidualnym państwom. Analizując przepisy pra-

${ }^{20}$ Dz.U. 1993, nr 61, poz. 284; w stosunku do Rzeczypospolitej Polskiej weszła ona w życie dnia 19 stycznia 1993 r., na podstawie Oświadczenia rządowego z dnia 7 kwietnia 1993 r. w sprawie ratyfikacji przez Rzeczpospolitą Polską Konwencji o ochronie praw człowieka i podstawowych wolności, sporządzonej w Rzymie dnia 4 listopada 1950 r., zmienionej następnie Protokołami nr 3, 5 i 8 oraz uzupełnionej Protokołem nr 2 (Dz.U. 1993, nr 61, poz. 285), ustawy z dnia 2 października 1992 r. o ratyfikacji Konwencji o Ochronie Praw Człowieka i Podstawowych Wolności (Dz.U. 1992, nr 85, poz. 427).

${ }^{21} \mathrm{http}: / /$ strasburgre.msz.gov.pl/pl/o_re/o_radzie_europy_info/ (dostęp 29.12.2016).

${ }^{22}$ Szerzej na temat pozycji i charakteru Komisji Weneckiej zob. J. Kociubiński, Przestrzeganie prawnomiędzynarodowych standardów ustroju państwa (analiza działalności Komisji Weneckiej), „Państwo i Prawo” 2016, nr 12, s. 39 i n. 
wa krajowego, Komisja Wenecka identyfikuje potencjalne niezgodności ze standardami europejskimi lub luki w prawie. Komisja Wenecka ocenia teksty konstytucyjne i inne uregulowania o charakterze systemowym (np. prawo wyborcze, prawo dotyczące mniejszości lub niezależności sądownictwa). Jej opinie nie są wiążące, nie istnieje również bezpośredni związek prawny między ewentualnym stwierdzeniem przez Komisję, że doszło do ryzyka naruszenia albo naruszenia standardów praworządności lub demokratycznego państwa prawnego a wszczęciem procedury na forum Rady Europy przewidzianej jako reakcja na takie naruszenia (procedura zawieszenia lub usunięcia z Rady Europy) $)^{23}$.

Z kolei zgodnie $\mathrm{z}$ art. 2 TUE Unia opiera się na wartościach poszanowania godności osoby ludzkiej, wolności, demokracji, równości, państwa prawnego, jak również poszanowania praw człowieka, w tym praw osób należących do mniejszości. Wartości te są wspólne Państwom Członkowskim w społeczeństwie opartym na pluralizmie, niedyskryminacji, tolerancji, sprawiedliwości, solidarności oraz na równości kobiet i mężczyzn.

Traktat ten przewiduje również procedurę stwierdzenia zaistnienia zagrożenia dla tych wartości. Zgodnie z art. 7 TUE na uzasadniony wniosek jednej trzeciej Państw Członkowskich, Parlamentu Europejskiego lub 94 Komisji Europejskiej, Rada Europejska (dalej: Rada), stanowiąc większością czterech piątych swych członków po uzyskaniu zgody Parlamentu Europejskiego, może stwierdzić istnienia wyraźnego ryzyka poważnego naruszenia przez Państwo Członkowskie wartości, o których mowa $\mathrm{w}$ art. 2. Przed dokonaniem takiego stwierdzenia Rada wysłuchuje dane Państwo Członkowskie i, stanowiąc zgodnie $z$ tą samą procedura, może skierować do niego zalecenia. Rada następnie regularnie bada, czy powody dokonania takiego stwierdzenia pozostają aktualne.

Rada, stanowiąc jednomyślnie na wniosek jednej trzeciej Państw Członkowskich lub Komisji Europejskiej i po uzyskaniu zgody Parlamentu Europejskiego, może także stwierdzić, po wezwaniu Państwa Członkowskiego do przedstawienia swoich uwag, poważne i stałe naruszenie przez to Państwo Członkowskie wartości, o których mowa w art. 2. W konsekwencji Rada, stanowiąc większością kwalifikowaną, może zdecydować o zawieszeniu niektórych praw wynikających ze stosowania Traktatów dla tego Państwa Członkowskiego, łącznie z prawem do głosowania przedstawiciela rządu tego Państwa Członkowskiego w Radzie. Rada uwzględnia przy tym możliwe skutki takiego zawieszenia dla praw i obowiązków osób fizycznych i prawnych. Rada może następnie, stanowiąc większością kwalifikowaną, zdecydować

${ }^{23}$ Art. 3 w związku z art. 7 i art. 8 Statutu Rady Europy. 
o zmianie lub uchyleniu środków zgodnie z wskazanymi wyżej postanowieniami, w przypadku zmiany sytuacji, która doprowadziła do ich ustanowienia ${ }^{24}$.

Biorąc pod uwagę powyższe uprawnienia organizacji międzynarodowych, których członkiem jest Polska, oraz stanowisko Trybunału Konstytucyjnego odnośnie do zakresu kompetencji nieprzekazywalnych, należy zatem odpowiedzieć na pytanie, czy potencjalne podjęcie działań przez Radę Europy w trybie art. 3 w związku z art. 7 i art. 8 Statutu Rady Europy lub w trybie art. 7 TUE nie stanowi naruszenia zasady suwerenności.

Należy podkreślić, że już u progu członkostwa Polski w Unii Europejskiej Trybunał Konstytucyjny przypominał, że suwerennie ratyfikując - na podstawie wyniku przeprowadzonego referendum ogólnokrajowego - Traktat akcesyjny i Akt dotyczący warunków przystąpienia ${ }^{25}$, Rzeczpospolita Polska suwerennie uznała Traktat ustanawiający Wspólnotę Europejską za wiążące ją prawo międzynarodowe (art. 9 Konstytucji). Postanowieniami tego Traktatu pozostają kwestionowane przez wnioskodawców art. 202 i art. 203 TWE $^{26}$.

W kontekście zarzutu dotyczącego niezgodności unormowań Traktatu akcesyjnego oraz Aktu dotyczącego warunków przystąpienia ze sformułowaniami preambuły do Konstytucji, w części odnoszącej się do suwerenności Narodu Polskiego, Trybunał podkreślił wówczas, że przed-

${ }^{24} \mathrm{O}$ dotychczasowej praktyce stosowania tych regulacji zob. M. Wiebusch, The role of regional organizations in the protection of constitutionalism, International IDEA Discussion Paper 17/2016, http://www.idea.int/news-media/news?field_workregion_target_id=280627 (dostęp 29.12.2016).

${ }_{25}$ Traktat między Królestwem Belgii, Królestwem Danii, Republiką Federalną Niemiec, Republiką Grecka, Królestwem Hiszpanii, Republiką Francuską, Irlandia, Republiką Włoska, Wielkim Księstwem Luksemburga, Królestwem Niderlandów, Republiką Austrii, Republiką Portugalska, Republiką Finlandii, Królestwem Szwecji, Zjednoczonym Królestwem Wielkiej Brytanii i Irlandii Północnej (Państwami Członkowskimi Unii Europejskiej) a Republiką Czeska, Republiką Estońską, Republiką Cypryjska, Republiką Łotewska, Republiką Litewska, Republiką Węgierską, Republiką Malty, Rzecząpospolitą Polską Republiką Słowenii, Republiką Słowacką dotyczący przystąpienia Republiki Czeskiej, Republiki Estońskiej, Republiki Cypryjskiej, Republiki Łotewskiej, Republiki Litewskiej, Republiki Węgierskiej, Republiki Malty, Rzeczypospolitej Polskiej, Republiki Słowenii i Republiki Słowackiej do Unii Europejskiej, podpisany w Atenach w dniu 16 kwietnia 2003 r. (Dz.U. z 2004 r., nr 90, poz. 864; dalej: Traktat akcesyjny) oraz stanowiący jego integralną część - Akt dotyczący warunków przystąpienia Republiki Czeskiej, Republiki Estońskiej, Republiki Cypryjskiej, Republiki Łotewskiej, Republiki Litewskiej, Republiki Węgierskiej, Republiki Malty, Rzeczypospolitej Polskiej, Republiki Słowenii i Republiki Słowackiej oraz dostosowań w Traktatach stanowiących podstawę Unii Europejskiej (dalej: Akt dotyczący warunków przystąpienia).

${ }^{26}$ Traktat ustanawiający Wspólnotę Europejską (tekst skonsolidowany Dz.Urz. WE C 325 z 24.12.2002, s. 1-184). 
miotem przekazania - podlegającego ocenie konstytucyjności pod kątem respektowania suwerenności i bezpieczeństwa państwa (zgodnie z wymogami art. 126 ust. 2 Konstytucji) - są kompetencje organów władzy państwowej „w niektórych sprawach”. Zostały one uprzednio ukształtowane "na podstawie i w ramach Konstytucji”, a zatem zgodnie z jej aksjologia, wyrażoną m.in. w sformułowaniach preambuły. Ponadto zauważył, że preambuła, akcentując znaczenie odzyskanej przez Polskę możliwości suwerennego i demokratycznego stanowienia o swoim losie, deklaruje jednocześnie potrzebę „,współpracy ze wszystkimi krajami dla dobra Rodziny Ludzkiej”, przestrzegania obowiązku "solidarności z innymi” oraz uniwersalnych wartości, takich jak prawda i sprawiedliwość. Powinność ta odnosi się nie tylko do stosunków wewnętrznych, ale również zewnętrznych $^{27}$. Dodał również, że analogiczne wartości, należące do wspólnego dziedzictwa prawnego państw europejskich, determinują cele i kierunek działania Wspólnot i Unii Europejskiej ${ }^{28}$. Podobnie, w przypadku przystąpienia do Rady Europy, istnienie wspólnego rdzenia aksjologicznego i zbliżonego rozumienia zasad demokracji, rządów prawa i niezależności władzy sądowniczej nie budziło wątpliwości, a wręcz było nierozerwalnie związane z poddaniem się jurysdykcji ETPC ${ }^{29}$.

Konstytucja RP, prawo wspólnotowe oraz dorobek orzeczniczy

96 ETPCz oparte są na tym samym zespole wspólnych wartości wyznaczających naturę demokratycznego państwa prawnego oraz katalog i treść praw podstawowych. Okoliczność ta istotnie ułatwia współstosowanie i obopólnie przyjazną wykładnię prawa krajowego, unijnego i Konwencji w świetle art. 9 Konstytucji statuującego obowiązek RP do przestrzegania wiążącego ją prawa międzynarodowego.

Zarówno tryb przekazania, jak i przedmiot przekazania zachowuje cechę pozostawania „w zgodzie z konstytucją" (traktowaną integralnie, wraz z preambułą) jako „najwyższym prawem Rzeczypospolitej”. Ewentualna zmiana trybu oraz przedmiotu przekazania (kompetencji przekazywanych) wymaga przestrzegania rygorów zmiany konstytucji określonych w art. 235 tego aktu, tj. respektowania unormowań konstytucji jako „prawa najwyższego Rzeczypospolitej”. Zasadnicze znaczenie, z punktu widzenia suwerenności oraz ochrony innych wartości konstytucyjnych, ma ograniczenie możliwości przekazania kompetencji do „niektórych spraw” (a zatem bez naruszenia „rdzenia” uprawnień, umożliwiające-

${ }^{27}$ Zob. także P. Winczorek, Konstytucja RP a prawo wspólnotowe, „Państwo i Prawo” 2004, nr 11, s. 7.

${ }^{28}$ Wyrok Trybunału Konstytucyjnego z dnia 11 maja 2005 r., sygn. akt K 18/04, OTK ZU nr 5/A/2005, poz. 49.

${ }_{29}$ R. Kuźniar, Prawa Człowieka. Prawo, instytucje, stosunku międzynarodowe, Warszawa 2002, s. 196. 
go - w zgodzie z preambułą - suwerenne i demokratyczne stanowienie o losie Rzeczypospolitej). A contrario zmiana wskazanych w preambule oraz poręczonych w aktach prawnomiędzynarodowych zasad ustroju czy szerzej - przebudowa aksjologii państwa, również wymagać będzie zmiany w konstytucji i odpowiedniej modyfikacji zobowiązań międzynarodowych.

W tym kontekście potencjalnie działania podjęte przez Radę w trybie art. 7 TUE (lub przez Radę Europy w trybie art. 3 w związku z art. 7 i art. 8 Statutu Rady Europy) w celu ochrony określonego porządku konstytucyjnego, rozumianego jako zespół wartości i zasad nierozerwalnie związanych z koncepcją ustroju przyjętą i poręczoną postanowieniami Konstytucji z 1997 r., w obecnym stanie prawnym nie mogą być postrzegane jako ingerencja w sprawy wewnętrzne kraju, a przez to niezgodna z zasadą suwerenności, o której mowa w art. 4 Konstytucji ${ }^{30}$. Należy je raczej traktować w kategoriach wywiązywania się przez RP z wiążących ją zobowiązań międzynarodowych.

\section{Literatura}

Banaszak B., Konstytucja Rzeczypospolitej Polskiej. Komentarz, Warszawa 2012.

Bień-Kacała A., Bezpieczeństwo w Konstytucji RP z 1997 r. - wstępna diagnoza, „Przegląd Prawa Konstytucyjnego" 2015, nr 2.

Brzeziński M., Rodzaje bezpieczeństwa państwa, [w:] S. Sulowski, M. Brzeziński (red.), Bezpieczeństwo wewnętrzne państwa. Wybrane zagadnienia, Warszawa 2009.

Ciapała J., Wokót pojmowania i wykonywania suwerenności w warunkach członkostwa w Unii Europejskiej - kilka uwag podstawowych, lecz czy wystarczajacych?, „Gdańskie Studia Prawnicze" 2014, t. XXXI.

Fehler W., Bezpieczeństwo wewnętrzne wspótczesnej Polski. Aspekty teoretyczne i praktyczne, Warszawa 2012.

Kociubiński J., Przestrzeganie prawnomiędzynarodowych standardów ustroju państwa (analiza działalności Komisji Weneckiej), „Państwo i Prawo” 2016, nr 12.

Kuźniar R., Prawa Człowieka. Prawo, instytucje, stosunku międzynarodowe, Warszawa 2002.

Lis W., Bezpieczeństwo wewnętrzne i porządek prawny jako sfera działania administracji publicznej, Lublin 2015.

Osierda A., Prawne aspekty pojęcia bezpieczeństwa publicznego i porzadku publicznego, „Studia Iuridica Lublinensia" 2014, nr 23, http://studiaiuridica.umcs.pl (dostęp 02.03.2017).

Sekściński A., Bezpieczeństwo wewnętrzne w ujęciu teoretycznym. Geneza i współczesne rozumienie w naukach politycznych, „Kwartalnik Naukowy OAP UW e-Politikon” 2013, http:// oapuw.pl/e-politikon-nr-62013/ (dostęp 29.12.2016).

${ }^{30}$ Czy też naruszającą prawo Narodów do samostanowienia (art. 1 Międzynarodowego Paktu Praw Obywatelskich i Politycznych z dnia 19 grudnia 1966 r., Dz.U. 1977, nr 38, poz. 167). 
Wiebusch M., The role of regional organizations in the protection of constitutionalism, International IDEA Discussion Paper 17/2016, http://www.idea.int/news-media/news?field_ workregion_target_id=280627 (dostęp 29.12.2016).

Winczorek P., Konstytucja RP a prawo wspólnotowe, „Państwo i Prawo” 2004, nr 11.

Wiśniewski B., Zalewski S., Podleś D., Kozłowska K., Bezpieczeństwo wewnętrzne Rzeczypospolitej Polskiej, Warszawa 2004.

Wojtyczek K., Konieczność jako legitymizacja działań władzy w demokratycznym państwie prawnym, „Państwo i Prawo” 1994, nr 9.

Zięba-Załucka H., Konstytucyjne aspekty bezpieczeństwa, „Studia Iuridica Liblinensia” 2014, nr 22.

\section{Akty prawne}

Traktat z Lizbony zmieniający Traktat o Unii Europejskiej i Traktat ustanawiający Wspólnotę Europejska, sporządzony w Lizbonie dnia 13 grudnia 2007 r. (Dz.U. z 2009 r., nr 203, poz. 1569).

Traktat o Unii Europejskiej (Dz.Urz. C 202 z 07.06.2016).

Statut Rady Europy przyjęty w Londynie dnia 5 maja 1949 r. (Dz.U.1994.118.565)

Konwencja o ochronie praw człowieka i podstawowych wolności, sporządzonej w Rzymie dnia 4 listopada 1950 r. (Dz.U.1993.61.284).

Oświadczenie rządowe z dnia 7 kwietnia 1993 r. w sprawie ratyfikacji przez Rzeczpospolitą Polską Konwencji o ochronie praw człowieka i podstawowych wolności, sporządzonej w Rzymie dnia 4 listopada 1950 r., zmienionej następnie Protokołami nr 3, 5 i 8 oraz uzupełnionej Protokołem nr 2 (Dz.U.1993.61.285).

Oświadczenie rządowe z dnia 20 maja 1994 r. w sprawie przystąpienia Rzeczypospolitej Polskiej do Statutu Rady Europy, przyjętego w dniu 5 maja 1949 r. w Londynie (Dz.U.1994.118.566).

Ustawa z dnia 2 października 1992 r. o ratyfikacji Konwencji o Ochronie Praw Człowieka i Podstawowych Wolności (Dz.U.1992.85.427).

Traktat między Królestwem Belgii, Królestwem Danii, Republiką Federalną Niemiec, Republiką Grecka, Królestwem Hiszpanii, Republiką Francuską, Irlandia, Republiką Włoską, Wielkim Księstwem Luksemburga, Królestwem Niderlandów, Republiką Austrii, Republiką Portugalską, Republiką Finlandii, Królestwem Szwecji, Zjednoczonym Królestwem Wielkiej Brytanii i Irlandii Północnej (Państwami Członkowskimi Unii Europejskiej) a Republiką Czeska, Republiką Estońska, Republiką Cypryjska, Republiką Łotewska, Republiką Litewską, Republiką Węgierską, Republiką Malty, Rzecząpospolitą Polska, Republiką Słowenii, Republiką Słowacką dotyczący przystąpienia Republiki Czeskiej, Republiki Estońskiej, Republiki Cypryjskiej, Republiki Łotewskiej, Republiki Litewskiej, Republiki Węgierskiej, Republiki Malty, Rzeczypospolitej Polskiej, Republiki Słowenii i Republiki Słowackiej do Unii Europejskiej, podpisany w Atenach w dniu 16 kwietnia 2003 r. (Dz.U. z 2004 r., nr 90, poz. 864) oraz stanowiący jego integralną część - Akt dotyczący warunków przystąpienia Republiki Czeskiej, Republiki Estońskiej, Republiki Cypryjskiej, Republiki Łotewskiej, Republiki Litewskiej, Republiki Węgierskiej, Republiki Malty, Rzeczypospolitej Polskiej, Republiki Słowenii i Republiki Słowackiej oraz dostosowań w Traktatach stanowiących podstawę Unii Europejskiej. 
Traktat ustanawiający Wspólnotę Europejską (tekst skonsolidowany Dz.Urz. WE C 325 z 24.12.2002).

Międzynarodowy Pakt Praw Obywatelskich i Politycznych z dnia 19 grudnia 1966 r. (Dz.U.1977.38.167).

\section{Orzecznictwo}

Wyrok TK z dnia 7 stycznia 2004 r., sygn. akt K 14/03, OTK ZU nr 1/A/2004, poz. 1.

Wyrok TK z dnia 11 maja 2005 r., sygn. akt K 18/04, OTK ZU nr 5/A/2005, poz. 49.

Wyrok TK z dnia 7 listopada 2005 r., sygn. akt P 20/04, OTK ZU nr 10/A/2005, poz. 111.

Wyrok TK z dnia 22 września 2006 r., sygn. akt U 4/06, OTK ZU nr 8/A/2006, poz. 109.

Wyrok TK z dnia 12 marca 2007 r., sygn. akt K 54/05, OTK ZU nr 3/A/2007, poz. 25.

Wyrok TK z dnia 15 stycznia 2009 r., sygn. akt K 45/07, OTK ZU nr 1/A/2009, poz. 3.

Wyrok TK z dnia 24 listopada 2010 r., sygn. akt K 32/09, OTK ZU nr 9/A/2010, poz. 110.

Wyrok TK z dnia 14 października 2015 r., sygn. akt Kp 1/15, OTK ZU nr 9/A/2015, poz. 147.

Wyrok TK z dnia 11 sierpnia 2016 r., sygn. akt K 39/16, OTK ZU nr A/2016, poz. 71. 